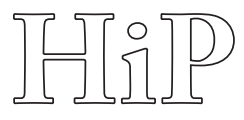

Historia i Polityka

No. $14(21) / 2015$, pp. 51-65

ISSN 1899-5160

www.hip.umk.pl

DOI: http://dx.doi.org/10.12775/HiP.2015.020

Natalia KARPCHUK

Lesia Ukrainka Eastern European University, Lutsk, Ukraine

\title{
Communication Policy Challenges of Ukraine in the Context of its European Integration
}

\begin{abstract}
Ukraine headed for European integration in 1998 when the Partnership and Cooperation Agreement between the European Union and Ukraine came into force. In the following years the Ukrainian society has been preparing to the state's prospective accession to the EU. However, on 21 November the course of Ukraine drastically changed and the Ukrainian society exploded. The lack of efficient communication policy, specifically close cooperation between the state authorities and the public, absolute disregard for Ukrainians' interests and requirements became the catalyst of mass protests. The aim of the article is to study the evolution of the development of communication interaction between the authorities and the civil society, to research the reasons of challenges Ukraine has faced in the past years. The article focuses on the legal grounds and the mechanisms of development of Ukraine's communication policy directions.
\end{abstract}

Keywords: communication policy, European integration, access to public information, authority, public interest

\section{Introduction}

The growing EU membership demonstrates the overall attractiveness of the multinational integration process. After the fall of the "Iron Curtain" Central and Eastern Europe had a choice "to remain out of the circle", joining only the free trade area (and supporting only inter-governmental cooperation), or "to enter the circle" of the EU. They chose the latter. By signing and ratifying treaties, Member States were convinced that the integration process had no clear end, but had clear goals that closely united all Europeans. This means that new members are attracted by the economic and political benefits of integration and that the transfer of a part of their national sovereignty to supranational institutions is not so terrible. 
The President's Decree approving the strategy of Ukraine's integration into the European Union of 11 June $1998^{1}$ became an important event in the process of establishing EU-Ukraine relations. It set the priorities of the executive authorities' activities up to 2007. The strategy takes into account the provisions of the EU Strategy for Ukraine of 4 October $1994^{2}$, the EU Common Strategy on Ukraine of 12 November $1999^{3}$, relevant decisions of the European Council, and declarations and other documents of the EU concerning Ukraine.

The topicality of the subject is determined by the problem that the communication policy of Ukraine, its challenges, the necessity of its elaboration and implementation have not been in the focus of academic attention. Predominantly, the scientists researched the issues of EU communication policy: Ph. Aldrin, J.-M. Utard, S. Meillier, M. Brugemman, E. Dacheux, Ch. Meyer, R. Upson, S. Kurpas, N. Karpchuk, Ye. Tychomyrova, etc.; or the interaction of state and local authorities with the public in Ukraine: H. Pocheptsov, N. Dniprenko, V. Bekh, V. Rizun, O. Susska, etc.

The author has set the main goal to study the modern challenges of Ukraine's communication policy in the context of its European integration process. The realization of the following tasks enables to achieve the goal:

- to clear up the principles of the EU communication policy as Ukraine is to adapt its legislation to the EU norms;

- to outline the prerequisites and problematic aspects of Ukraine's communication policy;

- to study the attempts to elaborate Ukraine's communication policy;

- to research communication failures of the President and the Government of Ukraine;

- to offer recommendations concerning Ukraine's communication policy.

Within the set goal the author analyzed legal documents of the EU and Ukraine in the sphere of communication policy. The paper used such techniques as systematic, interdisciplinary, comprehensive, comparative, historical, critical, et al.

1 Указ Президента України про затвердження стратегії інтеграції України до Європейського Союзу, 1998, http://zakon4.rada.gov.ua/laws/show/615/98 (accessed 4.01.2015).

$21790^{\text {th }}$ Council Meeting - General Affairs Council, 4 October 1994, http://aei.pitt.edu/ 3285/1/3285.pdf (accessed 4.01.2015).

3 Council Report to the European Council on the Implementation of the Common Strategy of the European Union on Ukraine, 2000 http://www.consilium.europa.eu/uedocs/cms_data/docs/ pressdata/en/misc/14202.en0.html (accessed 4.01.2015). 


\section{The Principles of the European Union Communication Policy}

In the European Union, Member States are connected by a complex system of communication and observation, i.e. by duties of regular reporting, by the system of benchmarking and monitoring, etc. This system is a new form of political coordination of the EU Member States as it serves as a permanent reminder of their responsibilities as members. In fact, the EU is a forum which is aimed at bringing together wills and volitional activities of its Member States in the framework of close mutual obligations ${ }^{4}$. Herewith, communication plays a key role because the general public makes evaluative judgments of a government's performance on the basis of what is communicated directly or indirectly through the mass media about government's decisionmaking, activities, and conduct of politicians.

In this study the author treats communication policy as a complex of principles and measures directed at objective and impartial manners of distributing information, establishing transparent relations between the government and the civil society, listening to the needs and demands of citizens, and involving citizens in the participation in the decision-making process.

The EU communication policy is grounded in the following principles:

- listening, because communication is a dialogue and European citizens want to be heard and influence the EU policy through active participation;

- communicating: citizens should be informed in simple terms about the impact of EU policies and activities on their daily lives;

- connecting with citizens by "going local": all EU activities should focus on solving demographic, national, and local problems through channels citizens prefer and in the language they understand.

Other important principles that lie at the heart of communication are:

- inclusiveness - all citizens should have access in their own language to information about matters of public concern through a wide range of channels, including the mass media and the Internet;

- diversity - European citizens come from widely diverse social and cultural backgrounds and hold a wide variety of political views, so the EU communication policy must respect the full range of views in the public debate;

\footnotetext{
4 М. Гердеген, Європейське право, 2008.

5 Action Plan to Improve Communicating Europe by the Commission, 2005, http://ec.europa. $\mathrm{eu} / \mathrm{dgs} / \mathrm{communication/pdf/comm-initiatives/2005-action-plan-improve-communicating-europe-}$ by-commission-sec2005-985_en.pdf (accessed 4.01.2015).
} 
- participation - citizens should have a right to express their views, be heard and have an opportunity for dialogue with the decision-makers ${ }^{6}$.

Having chosen the course towards European integration in 1998, Ukraine is to undertake obligations to conduct an efficient communication policy in compliance with the above principles. However, this process is quite complex, with numerous loudly announced steps and rather trivial practical implementation.

\section{Prerequisites of Ukraine's Communication Policy}

On the way to institutionalization of communicative relations between the Ukraine's authority and the general public the following key steps were made:

- 2002 - stipulation of mandatory formation of departments responsible for interaction with the media and public relations in the bodies of central and local authorities ${ }^{7}$;

- 2006 - the competences of the Deputy Prime Minister of Ukraine are changed to include formation and implementation of the public policy on transparency and openness of executive bodies and development of authorities' communication with the society ${ }^{8}$ (previously deputy prime ministers were responsible for the humanitarian direction and "the development and implementation of state policy in political and ideological spheres" 9 );

- 2010 - the approval of the Concept of the draft Law of Ukraine "On Fundamentals of the State Communication Policy"10.

However, the measures mentioned caused a number of problems because of their vague character, specifically:

${ }^{6}$ White Paper on a European Communication Policy, 2006, http://eur-lex.europa.eu/legalcontent/EN/TXT/PDF/?uri=CELEX:52006DC0035\&from=EN (accessed 4.01.2015).

7 Х.К. Перес Аапасаран, Принципь и преимущества децентрализации, Общая тетрадь 2006, no. 1 (36), p. 34.

${ }^{8}$ Про функціональні повноваження Прем'єр-міністра України, Першого віце-прем'єрміністра України, віце-прем’єр-міністрів України та Міністра Кабінету Міністрів України: Постанова Кабінету Міністрів України 27.01.2006, no. 74, (втратила чинність), http://zakon. rada.gov.ua/cgi-bin/laws/main.cgi?nreg=74-2006-\%EF (accessed 4.01.2015).

9 Про розподіц функціонацьних повноважень керівництва Кабінету Міністрів України: Постанова Кабінету Міністрів України 11.12.1995, no. 993-95 (втратика чинність), http://zakon.rada.gov.ua/cgi-bin/laws/main.cgi?nreg=993-95-\%EF (accessed 4.01.2015).

${ }^{10}$ Про схвалення Концепції проекту Закону України "Про основні засади державної комунікативної політики”: Розпорядження Кабінету Міністрів України 13.01.2010, no. 85, http://zakon.rada.gov.ua/cgi-bin/laws/main.cgi?nreg=85-2010-\%F0\&new=1 (accessed 4.01.2015). 
1. At the normative and legal level. Today communicative interaction between the state government, local authorities, the media, and the public are scattered in a number of legal acts, some of which are the decisions of the Cabinet of Ministers of Ukraine. Because of this, important instruments (public consultations, public examinations, etc.) are limited only to the executive branch. There are no common standards for information exchange between the authorities and the public. The mechanisms of public control over the activities of the government and organization of advocacy are still not defined. It should be noted that in the legislative and judiciary branches of Ukraine there are no departments of public relations ${ }^{11}$, and the communicative function is limited to providing press releases.

At the level of local authorities the boards (departments/sectors) of Internal Affairs and Public Relations are responsible for communication. They act under appropriate provisions. There are also departments responsible for handling the press and information. Responsibilities and spheres of influence of these two structural units are clearly defined ${ }^{12}$.

At the level of central authorities in 2002 the list of typical structural units was offered and, in particular, the presence of structural units responsible for interaction with the media and public relations was regulated ${ }^{13}$. However, differences in approaches to the functioning of information services in state bodies introduced in 2005 by the legislature ${ }^{14}$ (information management, information and analytical units, the press service, press centers, public relations centers, press office, press secretaries, and press attachés), introduced some confusion regarding the distribution of duties between them.

2. At the authorities' communication level. In 1995 the coordination of press services and related information and analytical departments of the executive

11 Комунікація: демократичні стандарти в роботі органів державноӥ влади, ТОВ “Вістка” 2008, pp. 41-42.

12 Про затвердження Типового положення про Головне управління у справах національностей та релігій Київської міської, управління (віААі ) у справах націонацьностей та релігій обласної, віААі у справах національностей та релігій Севастопольської міської державної аАміністрації: Постанова Кабінету Міністрів України 12.03.2008, no. 171, http://zakon.rada.gov. ua/cgi-bin/laws/main.cgi?nreg=171-2008-\%EF\&new=1 (accessed 4.01.2015).

13 Про упорядкування структури апарату центрацьних органів виконавчої вмади та його структурних підрозділів: Постанова Кабінету Міністрів України 15.10.2002, nо. 1550 (втратима чинність), http://zakonl.rada.gov.ua/cgi-bin/laws/main.cgi?nreg=1550-2002$\%$ EF\&new $=1$ (accessed 4.01.2015).

14 Про порядок висвітлення Аіяльності органів державної влади: Закон України віА 23 вересня 1997, no. 539, http://zakon.rada.gov.ua/cgi-bin/laws/main.cgi?nreg=539\%2F97-\%E2\%F0\& new $=1$ (accessed 4.01.2015). 
branch through the press service of the President of Ukraine was initiated ${ }^{15}$. The President's Press Service had to conduct monthly briefings and quarterly seminars of the heads of said services. The latter, in turn, had to inform the Administration of the President of Ukraine weekly on planned activities with the participation of heads of state bodies, held with the media participation, and jointly with the Press Service of the President of Ukraine they had to coordinate preparing the materials to be transmitted to the media; the materials should include the evaluation of foreign and domestic policy of the states and may cause a public outcry.

In 2002 the Office of Public Relations of the Department of Internal Policy of the Secretariat of the Cabinet of Ministers of Ukraine ensured the coordination of work on the creation of boards (departments) responsible for interaction with the media and public relations within the central and local executive. Methodological Recommendations of $2003^{16}$ described the interaction of these units with the Chief Department of Information Policy of the President's of Ukraine Administration, the Office of Public Relations of the Secretariat of the Cabinet of Ministers of Ukraine, relevant structural units of central and local executive, but no particular scheme was presented.

Until 2004 no one mentioned the importance of direct interaction with the broad public; the main stress was put only on thorough informing state officials and the mass media.

3. At the level of interaction with the public. In 2004 it was decided "to take measures to improve the structure of the Office of Public Relations of the Secretariat of the Cabinet of Ministers of Ukraine (...) to coordinate the work of central and local executive authorities concerning public consultation, public opinion surveys in order to take them in account in the formulation and implementation of state policy"17. So, the office included the sector of methodological work and coordination with central and local executive authorities aimed at consulting the public (the sector had existed by early 2006). The Department of

15 Про координацію роботи прес-служб та інформаційно-аналітичних піАрозділів органів державної виконавчої влади: Розпорядження Президента України віА 23.11.1995, no. 419, http://zakon.rada.gov.ua/cgi-bin/laws/main.cgi?nreg=419\%2F95-\%F0\%EF (accessed 4.01.2015).

16 Про затверАження Методичних рекомендацій щодо положень про управління (віААіли) з питань взаємодії з засобами масової інформації та зв'язків з громадськістю апаратів центральних і місцевих органів виконавчої влади: Наказ Аержавного комітету телебачення і радіомовлення України, Міністерства Юстиції України віА 26.03.2003, nо. 59 та віА 14.04.2003, np. 314/7, http:// zakon1.rada.gov.ua/cgi-bin/laws/main.cgi ?nreg=v0059603-03 (accessed 4.01.2015).

17 Про роботу центрацьних і місцевих органів виконавчої вцади щодо забезпечення віАкритості у своїй Аіямьності, зв'язків з громадськістю та взаємодії із засобами масової інформації: Розпорядження Кабінету Міністрів України віА 18.10.2004, http://zakon1.rada. gov.ua/cgi-bin/laws/main.cgi?nreg=759-2004-\%F0\&new $=($ accessed 4.01.2015). 
Communication of the authorities and the public became the assignee of the sector; however, the provisions regulating its activity and the requirements of coordination were not implemented.

In 2006 the Deputy Prime Minister was empowered with the function of developing communication between the authorities and the society. However, this step remained only formal and the model regulations on the Department of Internal Policy and Public Relation prove this fact. Under this document, units are responsible to and controlled by the head of the respective body of state authority. Therewith, the regulations on the Department of Press and Information have specified that these structural units are responsible to and controlled by the head of the state administration and State Committee on Television and Radio Broadcasting ${ }^{18}$, and the regulations on the Department of Nationalities and Religion have set the accountability of the units to the head of the respective state administration and State Committee on Nationalities and Religion ${ }^{19}$. This dual subordination is due to the fact that it is the State Committee on Television and Radio Broadcasting of Ukraine that provides the state policy in the news and publishing industries, and the State Committee on Nationalities and Religion provides the state policy in the field of relations with nationalities, migration, religion, and relations with churches and religious organizations.

The establishment of the Communication Center in the Cabinet of Ministers of Ukraine in $2009^{20}$ was a certain breakthrough in the development of cooperation between the government and the society. Previously, the Cabinet of Ministers of Ukraine had launched a number of communication projects such as the websites "Civil Society and Power" and "Government site for young citizens" but these projects were new in content rather than form. The Communication Center of the Government was an innovation both in form and content. The main objective of this ambitious project was to establish equal subject-to-subject communication on two levels: in real space in a specially equipped room at the Government House

18 Про затвердження Типового положення про управління у справах преси та інформації обласної, Севастопольської міської, управління преси та інформації Київської міської державної адміністрації: Постанова Кабінету Міністрів України віА 25.07.2007, no. 954, http:// zakon1.rada.gov.ua/cgi-bin/laws/main.cgi?nreg=954-2007-\%EF (accessed 4.01.2015).

19 Про затвердження Типового положення про Головне управління у справах націонацьностей та релігій Київської міської, управління (віААі ) у справах націонацьностей та релігій обласної, відАіл у справах національностей та релігій Севастопольської міської державної аАміністрації: Постанова Кабінету Міністрів України віА 12.03.2008, no. 171, http://zakon.rada. gov.ua/cgi-bin/laws/main.cgi?nreg=171-2008-\%EF\&new=1 (accessed 4.01.2015).

20 Положення про Секретаріат Кабінету Міністрів України 2009, http://www.kmu.gov.ua/ control/uk/publish/article?art_id=245395677\&cat_id=244824300 (accessed 4.01.2015). 
(Hrushevskoho St. 12/2) and virtual space via the Internet, i.e. online chat via TV, Skype, and other technology interactions.

In terms of the social dimension, the Communication Center is a technology of e-democracy and is intended to bring the communication standards of the Ukrainian authorities to the world ones. The Communication Center is founded on the new basic principles: 1 ) equality of all discourse participants which, unlike the previous model of vertical information sharing between the government and the people, introduced horizontal dialogue between the sides; 2) direct connection, i.e. without the mediation of the press; 3 ) openness with access available to anybody; 4) online interaction. The implementation of the latter two principles was made possible by new technologies, especially the Internet. This transition to the communication of the future is just beginning to take shape. Ukraine, like the rest of the word, is proceeding to the direct dialogue without mediators and borders; the society is changing as well as the technologies of cooperation between the authorities and the society $y^{21}$.

\section{The Attempts to Develop the Communication Policy}

An important step in the direction of interaction with the public was made by the Cabinet of Ministers of Ukraine Order of 13 January 2010 on the approval of the Law of Ukraine "On the fundamentals of the state communications policy". The work at the draft of the Ukrainian communication policy has been conducted since 2009. On 17 November 2009 a meeting of the working group of the Ministry of Justice was held to develop the Law of Ukraine "On the fundamentals of the state communications policy". As a result, a new version of the concept of the law was elaborated. The Ministry organized an open public discussion on the draft concept of the Law of Ukraine "On the fundamentals of the state communications policy" 22 . On 1 December 2009 the Cabinet held a communicative discourse "Prospects of the implementation of the communication policy in Ukraine", which presented opinions of scientists and representatives of the authority on the current trends in social communication ${ }^{23}$.

21 Н. Аніпренко, Комунікативний центр уряду - шиях до демократії, Комунікація 2012, no. 2, p. 84, http://pdp.org.ua/images/stories/materials/Communication-2_March2012_final.pdf (accessed 12.01.2015).

22 Аержавна комунікативна політика: якою їй бути? 2009, http://www.ucipr.kiev.ua/publications/derzhavna-komunikativna-politika-iakoiu-iii-buti/lang/\%5C (accessed 12.01.2015).

23 Комунікативна політика в Україні - перспективи запроваАження 2009, http://apitu.org. ua/node/1284 (accessed 12.01.2015). 
The purpose of the draft of the Law was to determine the methods of legal regulation to ensure cooperation between public authorities, local governments, the mass media, and the public on the principles of equal partnership that will strengthen democracy and develop the civil and information society. The task of the document was to formulate principles and directions of the state communication policy of Ukraine, its goals and priorities, as well as the rights and obligations of all parties in communication ${ }^{24}$.

According to the the draft of the Law, the main goals and principles of Ukraine's state communication policy are to be:

- promoting the establishment of the civil and information society in Ukraine;

- developing democratic standards of communication of state authorities, local governments, the public, and the media;

- implementing measures to improve the openness and transparency of state and local authorities;

- promoting the citizens' understanding of basic policy priorities, mechanisms of participation in state affairs management ${ }^{25}$.

The constituent components of Ukraine's communication policy are set to be:

- normative and legal regulation, i.e. structural and legal definition of principles, creation of an appropriate legal framework;

- socio-economic component, i.e. promotion of social stability, increasing the level of public trust in public authorities and local governments;

- organizing component, i.e. creating a system of communication of public authorities, local government, the mass media, and the public by means of identifying powers of subjects and implementing international best practices;

- civic education, i.e. education of a new generation by creating a communicative culture in people's minds ${ }^{26}$.

On 13 January 2011 the Law of Ukraine "On the access to public information"27 was adopted as a step to implement international legal obligations of Ukraine under Articles 18 and 19 of the International Covenant on Civil and Political Rights ${ }^{28}$.

\footnotetext{
${ }^{24}$ Концепція проекту Закону України "Про основні засади державної комунікативної політики” 2010, http://zakon2.rada.gov.ua/laws/show/85-2010-\%D1\%80 (accessed 12.01.2015).

${ }^{25}$ Ibidem.

26 Концепція проекту Закону України “Про основні засади державної комунікативної політики” 2010, http://zakon2.rada.gov.ua/laws/show/85-2010-\%D1\%80 (accessed 12.01.2015).

27 Закон України “Про доступ до публічної інформації" 2011, http://zakon4.rada.gov.ua/ laws/show/2939-17 (accessed 12.01.2015).

${ }^{28}$ International Covenant on Civil and Political Rights 1966, https://treaties.un.org/doc/Publication/UNTS/Volume\%20999/volume-999-I-14668-English.pdf (accessed 11.01.2015).
} 
The Law envisages the simplification of the access procedure to documents which are at the disposal of the public authority bodies. The law provides two ways of accessing information: 1) active, i.e. providing information on demand, 2) passive, i.e. obligatory publication of the information in the official newspapers, on official websites, on the notice boards or by any other means no later than within 5 working days from the date of the approval of the document (draft documents are to published not later than 20 working days before the date of review). The norm concerning obligatory publication on websites is a revolutionary one, enshrined in Ukrainian law for the first time. Owing to this requirement the need for many enquiries will disappear.

Since its adoption, the Law of Ukraine "On the access to public information" essentially replaced the potential Law on state communication policy; requests of citizens and media are interpreted as a universal method of interaction with the public. On the whole, its essence is efficient informing, but it substantially eliminates a level of genuine communication with direct discussions on important public issues between the authorities and the community.

\section{The Test of Authorities' Communication Efforts}

The Association Agreement with the EU became the test of communication efforts of Ukraine. The negotiations on the Association Agreement started on 5 March 2007 under the Presidency of V. Yushchenko. Until the autumn of 2013 the next president V. Yanukovych pursued a pro-European policy and the Government prepared the legislation of Ukraine to sign the Agreement with the EU. In March 2013 the government presented the concept of realization of the state policy in promoting and establishing communication with the public on European integration of Ukraine until $2017^{29}$, which stressed that one of the main directions of the state policy of Ukraine was to ensure integration of the country into the European political, economic, and legal space for the purpose of gaining membership in the European Union. The necessity of cooperation between the authorities and the civil society was discussed; the need to inform the public about the benefits and the need for European integration was specifically stressed. However, in November 2013 this course of Ukraine's domestic and foreign policy

29 Концепція реалізації державної політики у сфері інформування та налагодження комунікації з громадськістю з актуацьних питань європейської інтеграції України на період Ao 2017 p. 2013, http://zakon4.rada.gov.ua/laws/show/168-2013-\%D1\%80 (accessed 5.01.2015). 
was threatened. The Order of M. Azarov's government "On issues of conducting the Association Agreement between Ukraine, on the one hand, and the European Union, the European Atomic Energy Community and their member-countries, on the other hand" of 21 November 2013 sparked a wave of protests ${ }^{30}$. On 28 November 2013 at the $3^{\text {rd }}$ EU summit "Eastern Partnership" in Vilnius V. Yanukovych did not sign the Association Agreement between Ukraine and the EU. The official version of the authorities centered on economic risks associated with the reduction in turnover with Ukraine's eastern neighbors, and the "forced pause" in European integration ${ }^{31}$.

Within a week after the failure to sign the Agreement at the First National Channel the ministers talked about the weaknesses and threats of the Agreement. Everyone seemed to understand (except the Government and the President) that all the disadvantages should have been discussed much earlier, before the act of not-signing, having prepared the public for such a step. At that moment no justifications and excuses mattered. It was clear that the public was not informed, not ready, and as a result, it did not agree with the position of the President and the Government. The state authorities refused to listen to their citizens. The paradox was that V. Yanukovych had chosen the words "I will hear everyone" as his presidential election slogan. Had he heard, the Euromaidan might not have gathered.

It is interesting that Prime Minister M. Azarov "liked" to talk with Ukrainians on Facebook every Friday. He repeatedly stated that "it allows to establish a direct dialogue and get first-hand information. (...) It is with the help of journalists' reports and requests that the Government manages to respond to the public promptly and solve urgent problems" 32 . It is sure that such "listening" to the needs and requirements of citizens was only a simulation of dialogue and a tribute to the fashion of being present in the social media.

In December 2013 the second President of Ukraine L. Kuchma (supported by Presidents L. Kravchuk and V. Yushchenko) expressed confidence that the government made a mistake, paying little attention to dialogue with people: "We should

\footnotetext{
30 Уряд прийняв розпоряАження про призупинення процесу підготовки до укцадання Угоди про асоціацію з ЄС 2013, http://www.kmu.gov.ua/control/uk/publish/article?art_ id $=246864953$ (accessed 11.01.2015).

31 Янукович розповів про перспективи підписання угоди про асоціацію 2013, http://tsn. ua/politika/yanukovich-rozpoviv-pro-perspektivi-pidpisannya-ugodi-pro-asociaciyu-322743.html (accessed 11.01.2015).

32 Азарову нравится решать насущные проблемы через Facebook 2013, http://www.segodnya.ua/politics/pnews/Azarovu-nravitsya-reshat-nasushchnye-problemy-cherez-Facebook-440911. html 1 (accessed 9.02.2015).
} 
organize round tables and explain as simply as possible to people what is really going on. Otherwise, the crisis will only increase" 33 .

One attempt to stop the protests was the statement by First Deputy Prime Minister S. Azbuzov on 12 December 2013 about the beginning of the range of consultations on the implementation of the Association Agreement with the European Union to overcome the crisis "for Ukraine not to be lost for Europe, and for the European path not to be lost for Ukraine"34.

In January 2014 the MFA of Ukraine opened a "hotline" on the issues of the Association with the EU, which was run on Tuesdays and Thursdays for two hours, so anyone could get information on the political aspects of European integration, as well as on the visa regime between Ukraine and the EU. It was specifically stressed that "European integration remains a strategic priority, no alternative course for Ukraine" 35 (it should be noted that during November - December 2013 Foreign Affairs Ministry did not comment or explained the critical situation).

On 9 January 2014 the Ministry of Economic Development and Trade of Ukraine launched a "hotline" on Ukraine-EU cooperation targeted primarily at businesses for them to assess how European integration would affect business conditions in some sectors of the Ukrainian economy ${ }^{36}$.

In parallel with delayed steps of dialogue and information campaign on16 January 2014 in violation of the established voting procedure the Supreme Council of Ukraine adopted 10 laws aimed at narrowing the constitutional rights and freedoms of citizens, namely ${ }^{37}$ :

- restrictions on the freedom of assembly guaranteed by Article 39 of the Constitution (unwarranted strengthening accountability and imposition of additional restrictions);

- restrictions on the freedom of expression in the media and the Internet, creating conditions for censorship in the media and the Internet;

33 Кучма озвучим главную ошибку власти 2013, http://ubr.ua/ukraine-and-world/power/ kuchma-ozvuchil-glavnuu-oshibku-vlasti-267811 (accessed 9.01.2015).

34 Сергій Арбузов: Ми відновлюємо підготовку до піАписання Угоди про асоціацію з Європейським Союзом 2013, http://www.kmu.gov.ua/control/uk/publish/article?art_id=246916350\& cat_id=244276429 (accessed 9.02.2015).

35 МЗС України відкрив “гарячу мінію” з питань євроінтеграції 2014, http://zn.ua/POLITICS/minekonomrazvitiya-otkrylo-goryachuyu-telefonnuyu-liniyu-po-voprosam-evrointegracii-136195_.html (accessed 9.02.2015).

36 Минэкономразвития открыло “горячую телефонную Аинию” по вопросам евроинтеграции 2014, http://zn.ua/POLITICS/minekonomrazvitiya-otkrylo-goryachuyu-telefonnuyu-liniyu-po-voprosam-evrointegracii-136195_.html (accessed 9.02.2015).

37 Рада ухвалила закони, що відкривають шлях до масових репресій - фонд, ВіАродження 2014, http://www.pravda.com.ua/news/2014/01/16/7009773/ (accessed 9.01.2015). 
- registration of organizations receiving assistance from foreign organizations and individuals as "foreign agents"; introduction of the tax mechanisms limiting financial support for public activity;

- prohibition of gathering information about the financial position of judges, law enforcement officers, and their families (protection from anti-corruption investigative journalists);

- adoption of laws on extremism, which can be used against peaceful protesters.

The experts think these laws could pave the way to mass repressions against peaceful citizens ${ }^{38}$.

\section{Recommendations on Setting Efficient Communication "Authority - Citizens"}

All the communication failures of the authority listed above led to a massive explosion that changed the Ukrainian society. Today it is not enough to make a next declarative statement and to outline the excellent prospects for the future. The community needs constant report for each step of the Government and the President, not promises, but real action. The President and the Prime Minister are constantly present in the information field; they try to underline their interest in citizens and understanding their interests and needs. However, it is still very early to draw conclusions about the efficiency of their communication efforts.

The author considers it would be appropriate for the Ukraine's authority to take the following steps in order to improve communication with citizens:

- weekly television appearances of the President before the citizens of Ukraine, which would show that the President is not alienated from reality and understands what is happening in his country (President V. Yushchenko practiced weekly radio messages, modeled on effective communication with the Americans by T. Roosevelt, but very soon Yushchenko's speeches turned into blab on uncertain topics);

- regular television appearances of Prime Minister who would inform the public about specific steps to overcome the crisis in the country (currently Prime Minister A. Yatsenyuk uses this communication channel);

38 Украйнський парламент прийняв драконівські закони, The Financial Times 2014, http:// tvi.ua/new/2014/01/17/ukrayinskyy_parlament_pryynyav_drakonivski_zakony___the_financial_times (accessed 11.01.2015). 
- officials should really engage in social networking with citizens and should not use the mediation of some assistants who deliver only general ideas;

- introduction of e-governance, enabling democratic control and participation of citizens in the development and implementation of public policies;

- regular online advisory referendums in some cities to explore issues and initiatives to involve citizens, especially for city development (e.g. taking the experience of Sweden in this field ${ }^{39}$ );

- online discussion forums for consultation with citizens;

- projects to support innovative ideas that improve the involvement of citizens in the government activity, which could lead to less corruption and more effective government response to the needs of citizens;

- web site (e.g. like the site www.2030.fi in Finland ${ }^{40}$ ), that provides a forum to bloggers to speak about their vision of Ukraine in 2030. The site would allow to engage citizens through social media for their views and ideas to be heard still at an early stage;

- all proposed ideas really should be heard by government officials and taken into account, as often the government and citizens live as if in parallel worlds being bothered by their problems that do not match.

\section{Conclusions}

If Ukraine strives for gaining membership in the EU, it is to bring its legal norms in compliance with the EU standards. Consequently, Ukraine's communication policy should be grounded on the same principles as the EU communication policy, namely, listening, communicating, connecting with citizens by "going local", inclusiveness, diversity, and participation.

The importance of direct interaction with the broad public was not considered topical in Ukraine; the main stress was made only on thorough informing state officials and the mass media. The adopted legal norms were focused only on information dissemination (the EU has also passed through this stage). Besides, the adopted laws and regulations brought more confusion than clarity concerning

39 Citizen centric e-participation. A trilateral collaboration for democratic innovation. Case studies on e-participation policy: Sweden, Estonia and Iceland 2013, http://www.praxis.ee/fileadmin/tarmo/Projektid/Valitsemine_ja_kodanike\%C3\%BChiskond/citizen_centric_e_participation_veebi.pdf (accessed 12.01.2015).

${ }^{40}$ Citizens involved in shaping the future of Finland 2012, http://vnk.fi/ajankohtaista/ tiedotteet/tiedote/fi.jsp?oid=366665 (accessed 12.01.2015). 
responsibility and accountability. The Communication Center in the Cabinet of Ministers of Ukraine became a certain breakthrough in the development of cooperation between government and society as it offered the communication both in real and virtual spaces.

The draft of the Law "On the fundamentals of the state communication policy of Ukraine" was an attempt to determine the ways of legislative regulation to ensure cooperation between the authorities, local governments, the mass media, and the public on the principles of equal partnership that would strengthen democracy and contribute to the establishment of the civil and information society. However, it was replaced by the Law "On the access to public information" which once more replaced communication with informing.

The communications failures became obvious after not signing the Association Agreement with the EU which led to protest movements in Ukraine. In order to follow the EU communication principles and to establish a real dialogue with the citizens the Ukrainian state authorities should regularly address the society, arrange online discussions, interact via the social media, launch projects to collect innovative ideas, etc. It is urgent that all the citizens' ideas be really heard and implemented in next state policies. 